\title{
Efektivitas Metode Pembelajaran Berbasis TIK pada Mata Pelajaran Pekerjaan Dasar Elektromekanik
}

\author{
Hansi Effendi ${ }^{1}$, Mukhlidi Muskhir ${ }^{2}$, Roni Eka Rahmat ${ }^{3}$ \\ 1,2,3 Program Studi Pendidikan Teknik Elektro, Universitas Negeri Padang \\ email: hans_79@ft.unp.ac.id ${ }^{1}$, muskhir@ft.unp.ac.id ${ }^{2}$,roniekarahmat@gmail.com ${ }^{3}$
}

(Received: 19 April 2020/ Accepted: 29 April 2020 / Published Online: 20 Juni 2020)

\begin{abstract}
Abstrak
Pembelajaran yang berpusat kepada siswa dan menggunakan media serta cara-cara yang disukai siswa dengan penggunakan teknologi yang tepat akan membuat pembelajaran terasa menyenangkan. Penelitian ini bertujuan untuk melihat efektivitas pembelajaran berbasis Teknologi Informasi dan Komunikasi (TIK) pada mata pelajaran Pekerjaan Dasar Elektromekanik (PDE) di SMK Muhammadiyah 1 Padang. Penelitian ini menggunakan metode pre-eksperimental dengan desain one group pretest - posttest yang diterapkan pada kelas X TITL A sebagai kelas eksperimen. Pengumpulan data dilakukan dengan menggunakan instrument tes berupa soal objektif dengan jumlah soal sebanyak 20 item pertanyaan. Data dianalisis menggunakan ketuntasan klasikal dan gain score untuk melihat efektivitas penerapan metode pembelajaran berbasis TIK. Berdasarkan hasil penelitian, hampir semua siswa siswa tuntas dalam pembelajaran dan terjadi peningkatan hasil belajar siswa dengan kategori Besar. Dengan demikian penerapan metode pembelajaran berbasis TIK efektif diterapkan pada mata pelajaran PDE kelas X TITL A SMK Muhammadiyah 1 Padang.
\end{abstract}

Kata kunci: Efektivitas, Pembelajaran Berpusat Kepada Siswa, Pekerjaan Dasar Elektromekanik

\begin{abstract}
Student-centered learning and using media and ways that are suitable for the students and using the right technology will make learning more fun. This study aims to look at the effectiveness of Information and Communication Technology (ICT)-based learning in Electromechanical Basic Work $(E B W)$ subjects at SMK Muhammadiyah 1 Padang. This study used a pre-experimental method with one group pretest-posttest design applied to class X TITL A as an experimental class. Data collection was carried out using an objective test with a total of 20 questions. Data were analyzed using classical completeness and gain scores to see the effectiveness of applying ICT-based learning methods. Based on the results of the study, almost all students completed their learning and there was an increase in student learning outcomes in the large category. Thus the application of ICT-based learning methods effectively applied to EBW subjects in class X TITL A SMK Muhammadiyah 1 Padang.
\end{abstract}

Keywords: Effectiveness, Student-Centered Learning, Electromechanical Basic Work

\section{PENDAHULUAN}

Meningkatnya kemajuan zaman di bidang Teknologi Informasi dan Komunikasi (TIK) atau dalam dunia modernnya dikenal dengan istilah Information and Communication Technology (ICT) telah memberikan pengaruh yang besar di berbagai bidang kehidupan termasuk salah satunya di bidang pendidikan. Salah satu contohnya yaitu dengan maraknya penggunaan komputer sebagai media pembelajaran yang interaktif, praktis, dan menarik (Wiyono, 2016). Penerapan komputer tersebut memberikan dampak dan pengaruh yang positif terhadap perkembangan teknologi pembelajaran; memperluas akses kondisi terkini pendidikan; meningkatkan mutu pembelajaran; membuat manajemen pembelajaran menjadi efektif; dan menguatkan tata kelola dan administrasi pendidikan sehingga proses belajar dan 
pembelajaran dapat dilakukan secara efektif (Wiyono, 2016). Ditambah lagi berdasarkan penelitian didapatkan bahwa persepsi pendidik dan peserta didik terhadap penggunaan TIK dalam pembelajaran tidak jauh berbeda, di mana mereka berpendapat positif terhadap penggunaan teknologi dalam pembelajaran (Hendriyani \& Effendi, 2015).

Hal ini didukung dan diperkuat lagi dengan ditetapkannya penggunaan TIK pada Kurikulum 2013 butir ke-13 tentang penggunaan perangkat TIK untuk peningkatkan efektivitas dan efisiensi pembelajaran di mana hal ini dapat memberikan pengaruh yang signifikan terutama pada standar proses pembelajaran (Wiyono, 2016). Masyarakat zaman sekarang telah dihadapkan pada zaman masyarakat berbasis pengetahuan (knowledge-based society), zaman di mana masyarakat dituntut untuk memanfaatkan pengetahuannya demi meningkatkan produktivitas mereka didalam melakukan aktivitas sehari-hari (Artiya, Suartin, \& Effendi, 2017). Hal ini harus disikapi oleh siswa dengan tidak menganggap guru sebagai satu-satunya sumber belajar dan mereka harus aktif dalam menggali dan mengkonstruk pengetahuannya sendiri.

Di lain pihak, guru seharusnya sudah mengubah pola pikirnya dengan menjadikan dirinya sebagai fasilitator pembelajaran. Sebagai fasilitator, guru harus memfasilitasi siswa dengan mencari metode yang cocok, menyediakan media yang menarik, sehingga siswa tidak hanya termotivasi belajar tetapi senang belajar. Tetapi, berdasarkan observasi, fakta dilapangan menunjukan bahwa metode pembelajaran yang diterapkan masih berpusat pada guru (teacher-centered), di mana guru masih mendominasi aktivitas pembelajaran. Pendekatan pembelajaran ini tentu tidak efektif untuk diterapkan karena tidak berdampak pada peningkatkan nilai mutu hasil belajar siswa, siswa menjadi cepat bosan, dan pasif dalam proses pembelajaran sehingga kualitas belajar siswa menjadi rendah.

Selain itu, metode pembelajaran yang digunakan harus juga memperhatikan gaya belajar siswa dan juga mampu memotivasi siswa dalam belajar (Effendi, Effendi, \& Effendi, 2015; Effendi, Effendi, \& Effendi, 2017). Banyak metode maupun model pembelajaran yang dikembangkan oleh para ahli, tetapi tidak ada satu modelpun yang cocok untuk segala jenis situasi pembelajaran. Sehingga pembelajaran harus disesuaikan dengan situasi dan kondisi siswa dan juga karakteristik materi yang diaajarkan. Berdasarkan penelitian, hampir 60 persen siswa memiliki gaya belajar visual (Effendi, Effendi, \& Effendi, 2015; Effendi, Effendi, \& Effendi, 2017). Sehingga media yang cocok untuk gaya belajar ini diantaranya yaitu berupa gambar, grafik, ilustrasi, slide dengan tulisan yang berwarna-warni, dan videovideo pembelajaran.

SMK Muhammadiyah 1 Padang memiliki berbagai jurusan, salah satunya adalah jurusan Teknik Instalasi Tenaga Listrik (TITL). Di dalam jurusan Teknik Instalasi Tenaga Listrik ini terdapat mata pelajaran Pekerjaan Dasar Elektromekanik (PDE). Dari pengamatan peneliti selama melakukan observasi di sekolah tersebut terlihat bahwasannya pembelajaran masih terpusat kepada guru, siswa lebih banyak mendapatkan pemahaman dari guru, guru menyampaikan materi pelajaran menggunakan metode ceramah atau pendekatannya masih teacher-centered dan materinya banyak yang bersifat abstrak dan guru menjadi satu-satunya sumber belajar sehingga yang terjadi adalah komunikasi satu arah yang menyebabkan siswa tersebut menjadi pasif dan tidak berusaha menggali informasi dan memikirkan sendiri tentang materi pelajaran yang lebih dalam. Hal ini berakibat pembelajaran kurang berjalan efektif. Kondisi tersebut berdampak pada kualitas belajar siswa yang berada di bawah kriteria yang telah ditetapkan (KKM) yang dapat dilihat pada tabel 1. 
Tabel 1. Nilai Semester Genap Mata Pelajaran PDE Siswa Kelas X TITL SMK Muhammadiyah I Padang Tahun 2017 / 2018

\begin{tabular}{ccccc}
\hline \multirow{2}{*}{ Nilai } & \multicolumn{3}{c}{ Persentasi Ketuntasan Hasil Belajar } \\
\cline { 2 - 5 } & \multicolumn{2}{c}{$\boldsymbol{X}$ TITL $\boldsymbol{A}$} & \multicolumn{2}{c}{$\boldsymbol{X}$ TITL $\boldsymbol{B}$} \\
\cline { 2 - 5 }$\geq \mathbf{7 5}$ & orang & \% & orang & \% \\
\cline { 2 - 5 }$\geq \mathbf{7 5}$ & 8 & 26,7 & 7 & 23,5 \\
\hline$\sum$ & 22 & 73,4 & 23 & 76,7 \\
\hline
\end{tabular}

Tabel 1 menunjukkan nilai siswa pada mata pelajaran PDE. Dari tabel terlihat bahwa nilai hasil belajar siswa baik kelas A maupun kelas B masih banyak yang di bawah KKM. Ini berarti bahwa pembelajaran yang dilakukan belum efektif. Sehingga perlu dicari pendekatan lain dalam pembelajaran. Pembelajaran yang selama ini masih berpusat kepada guru sudah tidak cocok lagi digunakan dalam pembelajaran. Guru harus menggeser zona nyamannya yang masih terbiasa mengajar dengan metode ceramah tanpa memperhatikan aktivitas siswa. Selain itu dalam paradigma konstruktivisme, siswalah yang mengkonstruk pengetahuannya sendiri, Guru harus beralih menjadi fasilitastor dan motivator.

Penelitian ini mencoba melihat peran teknologi dalam pembelajaran. Banyak model pembelajaran dan metode pembelajaran berbasis TIK yang dikembangkan. Mulai dari berbasis web yang telah diuji efektivitasnya (Effendi, Soenarto, \& Sofyan, 2015), pembelajaran elektronik menggunakan Learning Management System (LMS) Moodle yang juga sudah terbukti efektivitasnya (Aurora \& Effendi, 2019), pembelajaran campuran atau dikenal dengan istilah blended learning (Effendi, 2019), flipped classroom yang merupakan tipe blended learning yang popular saat ini (Hamid \& Effendi, 2019), dan bahkan mobile learning yang juga banyak dikembangkan untuk digunakan dalam pembelajaran.

Pada penelitian ini teknologi yang digunakan yaitu video pembelajaan yang dapat diakses oleh siswa di kelas maupun di rumah tentang mata pelajaran PDE. Hal ini dirasa cocok untuk diterapkan dengan karakteristik mata pelajaran PDE yang bersifat abstrak. Dengan adanya video dan simulasi, diharapkan siswa mampu memahami mata pelajaran ini dengan lebih baik, termotivasi dalam belajar, dan mampu melihat secara langsung implementasi teori-teori dalam mata pelajaran ini. Sebenarnya, pemanfaatan video dalam pembelajaran telah ada pada model pembelajaran flipped classroom. Bedanya dengan yang dilakukan pada penelitian ini yaitu pelaksanaan pembelajaran di kelas bukan untuk meningkatkan kemampuan berfikir aras tinggi dan juga tidak berhubungan dengan taksonomi bloom, tetapi hanya ingin mengungkap dampak penggunaan teknologi pembelajaran, dalam hal ini video, terhadap hasil belajar siswa pada mata pelajarn PDE.

\section{METODE}

Penelitian ini bertujuan untuk melihat efektivitas penggunaan metode pembelajaran berbasis TIK yang dalam hal ini menggunakan video pembelajaran terhadap hasil belajar siswa dengan melihat peningkatan hasil belajar dalam penggunakan metode ini pada satu kelompok belajar sehingga metode penelitian yang digunakan yaitu penelitian preeksperimental dengan desain one group pretest-posttest. Penelitian ini dilaksanakan di kelas X TITL A SMK Muhammadiyah 1 Padang tahun 2018/2019 pada mata pelajaran Pekerjaan Dasar Elektromekanik (PDE) dengan jumlah siswa 30 orang. Teknik pengambilan sampel ditentukan melalui cluster random sampling.

Teknik pengumpulan data dilakukan dengan memberikan tes awal berupa pretest dan tes akhir berupa posttest. Instumen tes yang digunakan yaitu berupa soal objektif yang terdiri dari 20 item soal. Sebelum dilakukan penelitian, terlebih dahulu dilakukan uji validitas. Uji instrumen tersebut meliputi validitas isi dan validitas butir soal pretest dan soal posttest. Dari 
hasil validitas instrument didapatkan bahwa kedua puluh soal valid dan dapat digunakan dalam penelitian. Teknik analisis data menggunakan rumus ketuntasan klasikal, di mana jika $\geq 85 \%$ dari jumlah siswa memiliki nilai di atas Kriteria Ketuntasan Minimum (KKM), maka pembelajaran dianggap tuntas (Al-Tabany, 2017). Setelah itu dilakukan analisis gain score (Hake, 1999) untuk melihat peningkatan hasil belajar menggunakan metode ini terhadap hasil belajar siswa, seperti terlihat pada rumus (1), di mana:

$$
g=\frac{\text { skor posttest }- \text { skor pretest }}{\text { skor maksimum }- \text { skor pretest }}
$$

dimana kriteria dampaknya dapat dilihat pada Tabel 2, yaitu: (1) Tidak ada pengaruh, (2) Kecil, (3) Sedang, dan (4) Besar. Sebagai indicator dalam mencapai tujuan penelitian, pembelajaran hanya akan dianggap efektif jika metode pembelajaran berbasis TIK yang diterapkan memenuhi ketuntasan klasikal dan memiliki peningkatan hasil belajar minimal pada kategori Sedang.

\begin{tabular}{cc} 
Tabel 2. Kategori Analisis Effect Size \\
\hline Effect Size & Interpretasi \\
\hline $\mathbf{d}<\mathbf{0 , 2}$ & Tidak ada pengaruh \\
$\mathbf{0 , 2}<\mathbf{d}<\mathbf{0 , 5}$ & Kecil \\
$\mathbf{0 , 5}<\mathbf{d}<\mathbf{0 , 7}$ & Sedang \\
$\mathbf{d}>\mathbf{0 , 7}$ & Besar \\
\hline
\end{tabular}

\section{HASIL DAN PEMBAHASAN}

Data hasil belajar siswa yang dihasilkan dari penelitian ini terdiri dari hasil belajar siswa, ketuntasan klasikal, dan analisis skor peningkatan hasil belajar. Berikut deskripsi dari setiap hasil. Gambar 1 menunjukkan grafik distribusi hasil pretest. Dari grafik terlihat hasil pretest yang diperoleh di kelas X TITL A sebagai kelas eksperimen yaitu skor tertinggi sebesar 85 dan skor terendah sebesar 40. Rata-rata hasil pretest yang diperoleh yaitu sebesar 58,83 dengan standar deviasi 12,504. Frekuensi nilai terbanyak yang dicapai siswa yaitu pada interval 50. Siswa masih banyak yang belum mencapai ketuntasan. Terbukti dari rata-rata skor yang masih di bawah KKM yaitu 75 .

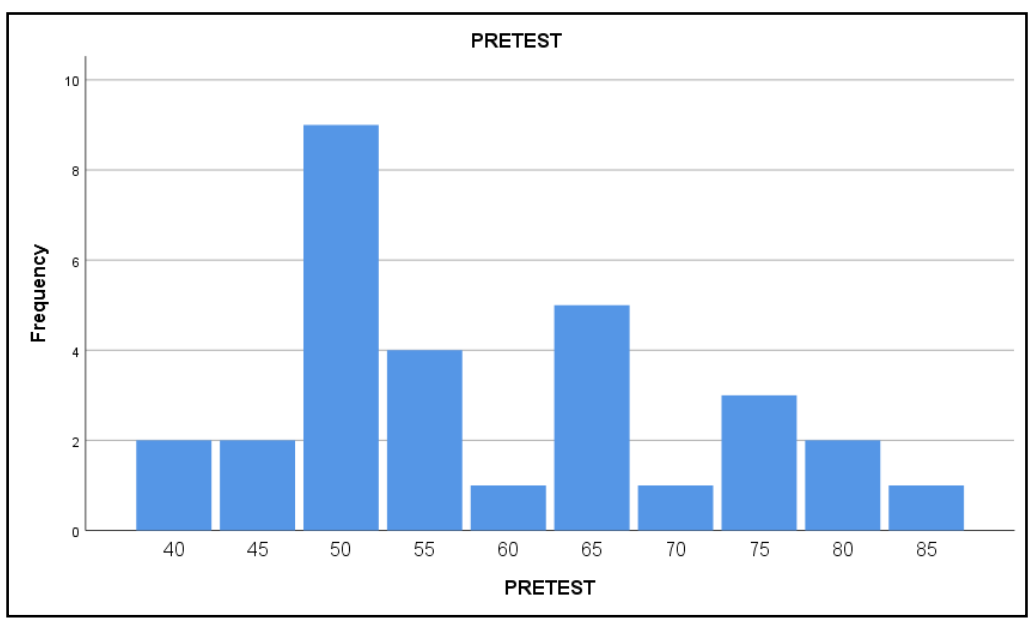

Gambar 1. Grafik Distribusi Frekuensi Pretest

Gambar 2 menunjukkan grafik distribusi frekuensi hasil posttest, di mana dari hasil posttest yang diberikan setelah menggunakan metode pembelajaran berbasis TIK dalam pembelajaran diperoleh nilai tertinggi 100 dan nilai terendah 65 dengan jumlah siswa 30 orang. Dengan 
menggunakan perhitungan statistik diperoleh nilai rata-rata sebesar 85,17 sedangkan standar deviasinya 9,33. Frekuensi nilai terbanyak yang dicapai siswa yaitu pada interval 90 .

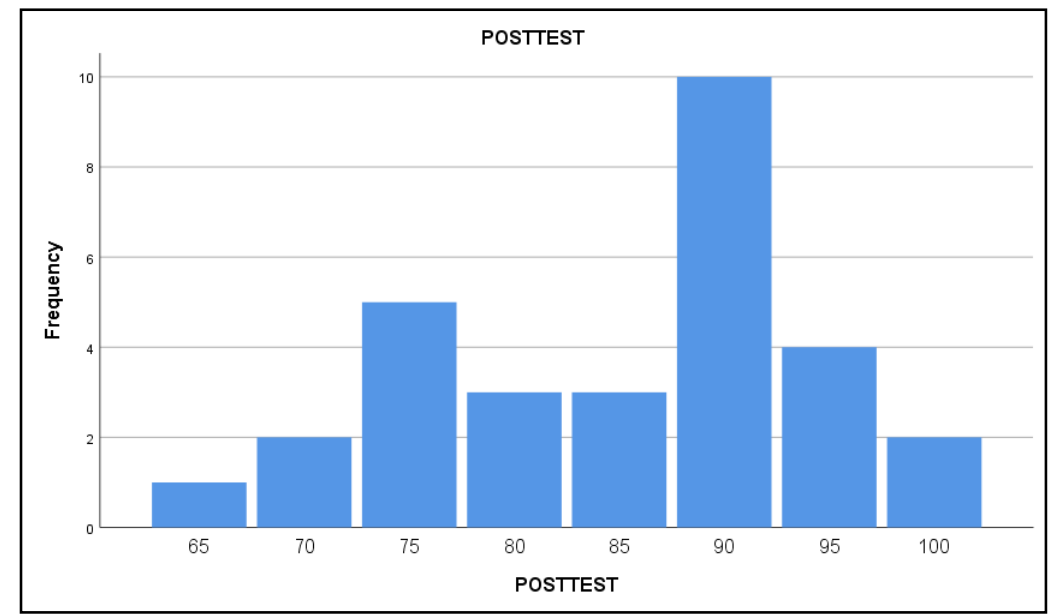

Gambar 2. Grafik Distribusi Frekuensi Hasil Posttest

Berdasarkan hasil posttest, siswa sudah banyak yang mencapai ketuntasan, di mana siswa yang tuntas mencapai 27 orang (90\%) dan yang belum tuntas sebanyak 3 orang (10\%). Lebih jauh lagi, berdasarkan Tabel 3 dapat disimpulkan bahwa secara klasikal siswa sudah memiliki penguasaan yang baik akan materi yang dipelajari. Penggunaan TIK dalam pembelajaran PDE dapat membuat siswa lebih aktif dan kreatif dalam proses pembelajaran yang diberikan. Melalui kesempatan untuk belajar mandiri siswa diberikan kesempatan untuk mengakses pelajaran mereka dengan menggunakan handphone yang mereka miliki dan dikontrol oleh guru secara langsung agar dapat menemukan solusi dari permasalahan yang diperoleh dalam pembelajaran yang telah dilakukan.

Tabel 3.Persentase Ketuntasan Klasikal Nilai Posttest Kelas Eksperimen.

\begin{tabular}{cccc}
\hline No & Hasil Belajar & Pencapaian & Persentase (\%) \\
\hline $\mathbf{1}$ & Rata-rata & 85,17 & - \\
$\mathbf{2}$ & Maksimum & 100 & - \\
$\mathbf{3}$ & Minimum & 65 & - \\
$\mathbf{4}$ & Jumlah Siswa Tuntas & 27 & 90 \\
$\mathbf{5}$ & Jumlah Siswa tidak tuntas & 3 & 10 \\
$\mathbf{6}$ & Jumlah Siswa keseluruhan & 30 & 100 \\
\hline
\end{tabular}

Terkait dengan peningkatan hasil belajar, terjadinya peningkatan hasil belajar siswa pada penelitian ini diukur dengan cara membandingkan perbedaan posttest dan pretest dengan perbedaan skor maksimum dan pretest untuk semua siswa seperti yang diperlihatkan pada rumus (1). Berdasarkan nilai pretest dan posttest atau hasil belajar siswa setelah dilakukan pembelajaran dengan penerapan metode pembelajaran berbasis TIK, maka didapatkan nilai peningkatan hasil belajar (gain score) sebesar 2,75 dengan kategori Besar. Berdasarkan ketuntasan klasikal dan gain score ini maka dapat disimpulkan bahwa metode pembelajaran dengan menggunakan TIK ini efektif dilakukan.

Penelitian ini menggunakan hasil belajar siswa sebagai variabel penelitian. Data yang pertama kali diambil pada penelitian ini yaitu data kemampuan awal siswa yang diambil sebelum diberikan perlakuan berupa pembelajaran berbasis TIK. Data diambil melalui test awal (pretest). Setelah itu subjek penelitian diberi perlakuan berupa pembelajaran dengan menggunakan TIK dengan cara memanfaatkan perangkat teknologi, di mana media yang digunakan adalah media video yang diakses dengan memanfaatkan handphone. Setelah kelas 
eksperimen diberi perlakuan, kemudian dilakukan test akhir (posttest) untuk melihat hasil capaian siswa setelah diberikan perlakukan.

Hasil posttest terlihat bahwa hasil belajar peserta didik mengalami peningkatan setelah diberi perlakuan menggunakan metode pembelajaran berbasis TIK. Dari hasil posttest diperoleh rata-rata hasil belajar siswa kelas eksperimen sebesar 85,17 dalam proses pembelajaran yang dilakukan selama lima minggu dengan empat kali pertemuan.

Hasil penelitian ini relevan dengan beberapa penelitian yang menyatakan bahwa penerapan metode pembelajaran berbasis TIK efektif digunakan untuk meningkatkan hasil belajar siswa (Bustanil, Asrowi, \& Ardianto, 2019; Izzudin \& Suharmanto, 2013). Pembelajaran dengan menerapan metode pembelajaran berbasis TIK pada penelitian ini sudah meningkat dengan ketuntasan klasikal 90\%. Dengan meningkatnya hasil belajar, maka efektivitas dalam pembelajaran sudah tercapai. Berdasarkan hasil ketuntasan klasikal, penerapan metode pembelajaran berbasis TIK telah memenuhi syarat sebagai pembelajaran yang efektif.

\section{SIMPULAN}

Berdasarkan hasil penelitian dengan desain pre-ekperimental one group pretest-posttest dan dianalisis dengan ketuntasan klasikal dan gain score didapatkan bahwa terjadi peningkatan hasil belajar 90\% siswa yang belajar dengan menggunakan TIK dengan kategori peningkatan Besar. Hal ini berarti bahwa penggunaan TIK dalam pembelajaran perlu dilakukan agar siswa termotivasi belajar karena lingkungan belajar sesuai dengan karakteristik mereka. Perlu kiranya saat ini guru-guru mulai menggeser pola pembelajaran mereka dari yang biasanya berpusat pada guru menjadi berpusat kepada siswa.

\section{REFERENSI}

Al-Tabany, T. I. B. (2017). Mendesain model pembelajaran inovatif, progresif, dan kontekstual: Konsep, Landasan, dan Implementasinya pada kurikulum 2013 (Kurikulum Tematik Integratif/KTI). Yogyakarta: Prenadamedia Group.

Artiya, D., Suartin, S., \& Effendi, H. (2017). Penerapan Metode Pembelajaran Aktif Quiz Team pada Mata Pelajaran Memahami Dasar-Dasar Elektronika di Kelas X TITL SMK Muhammadiyah 1 Padang. INVOTEK: Jurnal Inovasi Vokasional Dan Teknologi, 17(2), 27-30. https://doi.org/10.24036/INVOTEK/VOL17-ISS2/65

Aurora, A., \& Effendi, H. (2019). Pengaruh Penggunaan Media Pembelajaran E-learning terhadap Motivasi Belajar Mahasiswa di Universitas Negeri Padang. Jurnal Teknik Elektro Vokasional, 5(2), 11-16. Retrieved from http://ejournal.unp.ac.id/index.php/jtev/index

Bustanil, M., Asrowi, \& Ardianto, D. T. (2019). Pengembangan Media Pembelajaran Interaktif Berbasis Video Tutorial Di Sekolah Menengah Kejuruan. JTP - Jurnal Teknologi Pendidikan, 21(2), 119-134. https://doi.org/10.21009/JTP.V21I2.11568

Effendi, H. (2019). Blended Learning Effectiveness in Improving Learning Access in Higher Education. 5th UPI International Conference on Technical and Vocational Education and Training (ICTVET) 2018, 298-301. https://doi.org/https://dx.doi.org/10.2991/ictvet18.2019 .67

Effendi, H., \& Dwiyani, N. (2018). Learning Management System Berbasis Cloud sebagai Alternatif Pembelajaran bagi Guru Sekolah Menengah Pertama. Jurnal Teknologi Informasi Dan Pendidikan, 11(2), 80-84. Retrieved from http://tip.ppj.unp.ac.id/index.php/tip/article/view/146

Effendi, H., Soenarto, \& Sofyan, H. (2015). The Effectiveness of Web-Based Interactive Blended Learning Model in Electrical Engineering Courses. Research and Evaluation in Education, 1(2), 175-185. https://doi.org/http://dx.doi.org/10.21831/reid.v1i2.7140

Effendi, Z. M., Effendi, H., \& Effendi, H. (2015). Implikasi gaya belajar dalam desain 
blended learning. Jurnal Teknologi Informasi Dan Pendidikan, 8(1), 72-80. https://doi.org/https://doi.org/10.31227/osf.io/dxnrf

Effendi, Z. M., Effendi, H., \& Effendi, H. (2017). The Role of Locus Control and Learning Styles in The Development of The Blended Learning Model at PSU. International Journal of GEOMATE, 13(37), 75-80. https://doi.org/10.21660/2017.37.TVET025

Hake, R. R. (1999). Analizing Chanel Gain Scores. Retrieved from http://www.physics.indiana.edu/ sdi/AnalyzingChange-Gain.pdf

Hamid, A., \& Effendi, H. (2019). Flipped Classroom sebagai Alternatif Pembelajaran pada Mata Pelajaran Dasar Listrik dan Elektronika. Jurnal Teknik Elektro Dan Vokasional, $V(1), 81-86$.

Hendriyani, Y., \& Effendi, H. (2015). Persepsi Mahasiswa terhadap Penggunaan E-Learning dalam Pembelajaran Bahasa Pemograman di Fakultas Teknik UNP. Jurnal Teknologi Informasi \& Pendidikan, 8(1), 48-58. https://doi.org/10.31227/osf.io/w826a

Izzudin, A. M., \& Suharmanto, A. (2013). Efektivitas Penggunaan Media Pembelajaran Video Interaktif Untuk Meningkatkan Hasil Belajar Praktik Service Engine Dan Komponen-Komponennya. Journal Unnes, 2(2), 1-8.

Wiyono, K. (2016). Pengembangan Model Pembelajaran Fisika Berbasis ICT Pada Implementasi Kurikulum 2013. Jurnal Inovasi Dan Pembelajaran Fisika, 2(2), 123131. 